\title{
Characterization of Cathepsin D from the Skeletal Muscle of Fresh Water Fish, Tilapia mossambica
}

\author{
S. N. Doke, V. NINJOoR and G. B. NADKARNI \\ Biochemistry and Food Technology Division, Bhabha Atomic Research Centre, \\ Trombay, Bombay-85, India
}

Received November 26, 1979

\begin{abstract}
Cathepsin D (EC. 3.4.4.23) from the skeletal muscle of fresh water fish Tilapia mossambica was purified 114 -fold with $14 \%$ recovery by employing conventional gel chromatography procedures. The purified enzyme appeared to be homogeneous by polyacrylamide gel electrophoresis. The apparent molecular weight of the enzyme was found to be 38,000 by Sephadex G-100 column chromatography. The enzyme exhibited dual pH optima at $\mathrm{pH} 2.8$ and 3.8 when denatured hemoglobin was used as the substrate. However, the degradation of endogenous sarcoplasmic proteins occurred maximally at pH 5.0. The optimum temperature of enzyme assay was $50^{\circ} \mathrm{C}$. The enzyme displayed heat stability at $60^{\circ} \mathrm{C}$ in presence of substrate, while in the absence of substrate it lost $95 \%$ of activity during incubation for $60 \mathrm{~min}$ at $60^{\circ} \mathrm{C}$. Sulphydryl compounds and divalent metal ions had no effect on the enzyme activity. However $\mathrm{NaCl}$ at $10 \%$ concentration inactivated the enzyme almost completely.
\end{abstract}

Cathepsin D is a major lysosomal acid proteinase involved in the intracellular protein degradation. The role of this enzyme in altering the post-mortem textural attributes resulting in the accentuated formation of free amino acids, peptides and non-protein nitrogen during storage has been recognised in recent years. ${ }^{1 \sim 4)}$ Following the identification and characterisation of lysosomes in muscle cells by Bird and coworkers, ${ }^{5 \sim 9)}$ and after obtaining conclusive evidence pointing to the release of cathepsins and other hydrolases from the ageing meat, ${ }^{10,11)}$ there has been a stimulated interest on the role of cathepsin D in skeletal muscle degradative processes..$^{12,13\rangle} \quad$ Although the gastric $^{1 *}$ and microbial ${ }^{15}$ ) acid proteases have been purified and characterized extensively, the reports on cathepsin D from a variety of sources $^{13,16 \sim 18)}$ including fish skeletal muscle are conflicting with respect to $\mathrm{pH}$ optima, kinetic properties, molecular weight and multiplicity.

The present paper relates to purification of cathepsin D from the skeletal muscle of fresh water fish Tilapia mossambica, in an attempt to obtain information on stability and inhibition of the enzyme, with a view to formulating processing parameters for preservation of this fish species.

\section{MATERIALS AND METHODS}

\section{Materials}

Fish. Fresh water fish Tilapia mossambica, 14 $16 \mathrm{~cm}$ in average length were obtained from a commercial fish pond and were maintained in dechlorinated water in laboratory conditions in tanks maintained at $25 \sim 28^{\circ} \mathrm{C}$ for $4 \sim 6$ weeks for acclimatization. The diet of the fish consisted of fresh shrimps and continuous areation was provided by air circulation pump.

Reagents. Hemoglobin Type II, dithioerythreitol, cytochrome $c$, myoglobin, human serum albumin, ovalbumin, coomassie blue and acrylamide were procured from Sigma Chemical Co., St. Louis (MO, USA). DEAE cellulose (DE-32) was a product of Whatman Biochemicals, Ltd. (UK). Sephadex G-100, Sephadex A-50 and blue dextran were obtained from Pharmacia Fine Chemicals, Uppsala (Sweden).

All reagents of electrophoresis excluding acrylamide and coomassie blue were purchased from Eastman Kodak, Rochester (NY. USA). All other chemicals were of reagent grade and were used without further purification.

\section{Methods}

Assay of cathepsin D. Hemoglobin splitting activity was determined by a modification of Anson's method. ${ }^{10)}$ The assay mixture consisted of $0.5 \mathrm{ml}$ of 
$1 \%$ acid denatured hemoglobin solution, $\mathrm{pH} 3.8$, $0.1 \mathrm{ml}$ of enzyme solution and $0.4 \mathrm{ml}$ of $0.1 \mathrm{M}$ acetate buffer, $\mathrm{pH} 3.8$. The mixture was incubated at $37^{\circ} \mathrm{C}$ for $60 \mathrm{~min}$. The reaction was stopped by addition of $1 \mathrm{ml}$ of cold $10 \%$ trichloroacetic acid and stored at $0 \sim 4^{\circ} \mathrm{C}$ for $30 \mathrm{~min}$. The mixture was then centrifuged at $1500 \mathrm{rpm}$ for $15 \mathrm{~min}$ and a portion of the aliquot was taken up for the estimation of the released proteolytic end products. Appropriate blanks were kept and the measurement of products was carried out according to Miller's method ${ }^{20)}$ employing DL-tyrosine as standard. The unit of enzyme activity was expressed as nmol of tyrosine liberated/mg protein/hr.

Determination of protein concentration. The amount of protein in the enzyme preparations was determined by the method of Miller ${ }^{20)}$ employing bovine serum albumin as the standard.

Polyacrylamide gel electrophoresis. Purity of enzyme protein was ascertained by performing polyacrylamide disc gel electrophoresis in $7.5 \%$ gels according to the procedure of Davis ${ }^{21)}$ at $\mathrm{pH}$ 8.3. The duration of the electrophoresis was $60 \mathrm{~min}$ at $4^{\circ} \mathrm{C}$ at a current of $5 \mathrm{~mA} /$ tube. Gels were stained with coomassie blue and destained by the method of Fishbein. ${ }^{22}$ In another experiment, electrophoresis was carried out at $\mathrm{pH} 4.5$ employing acetic acid- $\beta$ alanine buffer. The unstained gels were sliced into $1 \mathrm{~cm}$ sections. Each section was homogenized with $1 \mathrm{ml}$ acetate buffer, $\mathrm{pH} 3.8$ with a glass and Teflon tissue homogenizer. Aliquots of the homogenates were tested for cathepsin D activity.

Molecular weight determination by gel filtration. Molecular weight was determined by descending gel filtration through a Sephadex G-100 column (90\% $2.5 \mathrm{~cm}$ ) equilibrated with $0.05 \mathrm{M}$ phosphate buffer $\mathrm{pH} 7.2{ }^{23}$ The void volume was determined by eluting blue dextran through the column. Elution volumes for the purified enzyme as well as for the marker proteins such as ovalbumin (mol. wt. 45,000) human serum albumin (mol.wt. 67,000) cytochrome $c$ (mol.wt. 12,400) and myoglobin (mol.wt. 17,800) were determined by gel filtration under identical conditions.

Preparation of crude enzyme. The fishes were sacrificed by decapitation, eviscerated and cleaned. The skin was completely removed. The skeletal muscle, devoid of bones, skin and connective tissue was collected in a beaker containing ice cold $0.25 \mathrm{M}$ sucrose containing $0.2 \mathrm{M} \mathrm{KCl}$. All procedures were carried out at $4{ }^{\circ} \mathrm{C}$. The $10 \%$ muscle homogenate was prepared in a blender employing intermittant speeds of high and low for $2 \mathrm{~min}$. The resulting homogenate was repeatedly subjected to five freeze-thaw treatments employing acetone and solid $\mathrm{CO}_{2}$. The homogenate was then filtered through two layers of surgical gauge and the filtrate was centrifuged at $17,300 \mathrm{~g}$ for $10 \mathrm{~min}$. The resulting supernatant served as the source of cathepsin D.

Degradation of endogenous proteins. Sarcoplasmic proteins from the skeletal muscle of the fish were isolated by a method described by King. ${ }^{24)}$ The assay of proteolytic activity on the endogenous substrates was conducted by incubating $6 \mathrm{ml}$ of sarcoplasmic protein fraction with $2 \mathrm{ml}$ of crude nezyme preparation with different $\mathrm{pH}$ environment in a shaker water bath maintained at $37^{\circ} \mathrm{C}$. At known intervals of time, $1 \mathrm{ml}$ of assay mixture was withdrawn and treated with $2 \mathrm{ml}$ of cold $10 \%$ TCA. The liberated amino acids were estimated as tyrosine equivalents. ${ }^{20)}$

\section{Purification of cathepsin D}

Step 1. Autolysis. The clear supernatant $(1250 \mathrm{ml})$ of the muscle homogenate obtained from $200 \mathrm{~g}$. fish was treated with streptomycin $(720 \mathrm{mg}$ ) and was allowed to undergo autolysis for $16 \mathrm{hr}$ at $37^{\circ} \mathrm{C}$. The preparation thereafter was centrifuged $(17,000 \mathrm{~g}$ for $10 \mathrm{~min})$ at $4^{\circ} \mathrm{C}$ to remove the sediment.

Step 2. Heat treatment. The supernatant obtained following autolysis was dialysed overnight against distilled water and was subjected to thermal treatment at $50^{\circ} \mathrm{C}$ for $5 \mathrm{~min}$. The precipitated protein was removed by centrifugation.

Step 3. Ammonium sulphate fractionation. The heat treated enzyme was subjected to ammonium sulphate fractionation $(0 \sim 80 \%)$ with gentle shaking. The sample was left overnight and centrifuged at $10,000 \mathrm{~g}$ for $30 \mathrm{~min}$. The precipitate was dissolved in a minimal volume of $0.05 \mathrm{M}$ phosphate buffer, $\mathrm{pH} 7.2$ and dialysed against the same buffer with several changes of the buffer. The dialysed fraction was centrifuged to eliminate insoluble precipitate.

Step 4. Gel filtration of Sephadex G-100. The enzyme was applied to a column $(90 \times 2.5 \mathrm{~cm})$ of Sephadex G-100 equilibrated with $0.05 \mathrm{~m}$ phosphate buffer, $\mathrm{pH} 7.2$ and eluted with the same buffer at a flow rate of $36 \mathrm{ml} / \mathrm{hr}$. The volume of fraction collected in each tube was $4.8 \mathrm{ml}$. The fractions containing enzyme activity were pooled and lyophilized.

Step 5. DEAE-chromatography. The lyophilized enzyme was dissolved in $0.01 \mathrm{M}$ Tris- $\mathrm{HCl}$ buffer, $\mathrm{pH} 8.2$ and dialysed against the same buffer. After dialysis the enzyme was applied to a DEAE-cellulose column $(40 \times 2 \mathrm{~cm})$ previously equilibrated with the above buffer. After eluting the unbound protein with Tris$\mathrm{HCl}$ buffer, $\mathrm{pH} 8.2$ a linear gradient of $0.01 \sim 0.3 \mathrm{M}$ $\mathrm{NaCl}$ in $0.01 \mathrm{M}$ Tris- $\mathrm{HCl}$ buffer, $\mathrm{pH} 8.2$ was applied. The flow rate was $60 \mathrm{ml} / \mathrm{hr}$ and $5 \mathrm{ml}$ fractions were collected. The fractions possessing cathepsin D activity were pooled, concentrated and dialysed against $0.01 \mathrm{~m}$ phosphate buffer $\mathrm{pH} 7.2$. 
Step 6. Gel filtration on Sephadex $G-100 \mathrm{II}$. The enzyme from step 5 was subjected to gel filtration at a flow rate of $18 \mathrm{ml} / \mathrm{hr}$ employing $0.01 \mathrm{M}$ phosphate buffer for elution. The active fractions obtained after the second gel filtration were pooled, concentrated and dialysed against $0.01 \mathrm{M}$ Tris- $\mathrm{HCl}$ buffer, $\mathrm{pH} 8.2$.

Step 7. DEAE-Sephadex A-50 chromatography. The enzyme obtained from step 6 was chromatographed over DEAE Sephadex A-50 $(30 \times 1 \mathrm{~cm})$ employing Tris- $\mathrm{HCl}$ buffer $\mathrm{pH} 8.2$ as the eluent. The active enzyme was collected by elution with a linear gradient of $0.05 \sim 0.5 \mathrm{M} \mathrm{NaCl}$ contained in the buffer. The fractions containing enzyme activity were again pooled, concentrated and dialysed against $0.01 \mathrm{M}$ phosphate buffer pH 7.2. The enzyme was rechromatographed on Sephadex G-100 as in Step 4 with a flow rate of $20 \mathrm{ml} / \mathrm{hr}$, and concentrated.

All operations were carried out at $0 \sim 4^{\circ} \mathrm{C}$ unless stated otherwise.

\section{RESULTS}

\section{Protolysis of endogenous substrate}

Figure 1 depicts the pattern of sarcoplasmic protein degradation by skeletal muscle cathep$\sin$ D. Among different $\mathrm{pH}$ environments tested, the enzyme cleaved the substrate maximally at pH 5.0. The reaction was also linear upto $4 \mathrm{hr}$.

\section{Purification of cathepsin $D$}

Cathepsin D from the skeletal muscle of fish Tilapia mossambica was purified about 114fold with $14 \%$ recovery as shown in Table I. The first step of purification did not yield higher enzyme activity. However, following dialysis and heat treatment, nearly $75 \%$ of the contaminating proteins were eliminated, with a

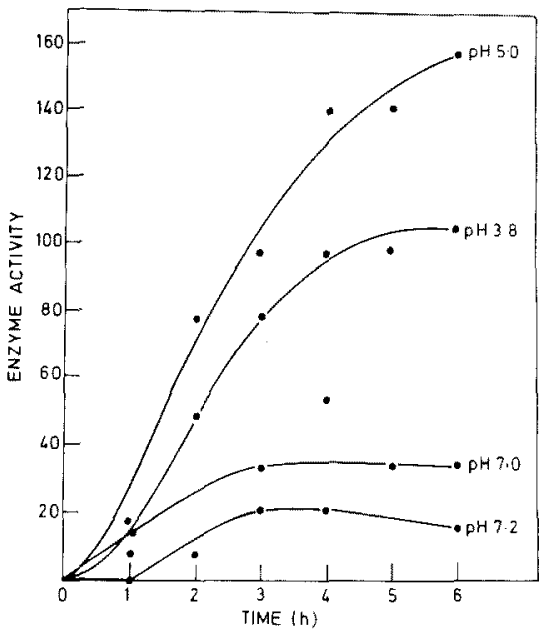

FIG. 1. Degradation of Endogenous Proteins by Skeletal Muscle Cathepsin D.

Sarcoplasmic protein fraction was isolated from skeletal muscle and after adjusting its $\mathrm{pH}$ to the desired levels it was allowed to react with the crude enzyme for varying periods. The buffers employed were $0.10 \mathrm{M}$ acetate ( $\mathrm{pH} 3.8$ and 5.0 ) and $0.05 \mathrm{M}$ phosphate ( $\mathrm{pH} 7.0$ and 7.2). The reaction was stopped by the addition of $10 \%$ TCA. The enzyme activity was expressed as nmol of tyrosine equivalents released $/ \mathrm{mg}$ protein.

four-fold increase in the activity. Although ammonium sulphate precipitation excluded $50 \%$ of the proteins, there was no marked increase in the activity. Gel filtration of ammonium sulphate fraction ( $0 \sim 80 \%$ saturation) on Sephadex G-100 yielded three protein peaks as shown in Fig. 2a. Cathepsin D emerged in a major protein peak, though a minor peak of activity was also observed. The ion exchange chromatography of pooled cathepsin D

Table I. Purification of Cathepsin D from the Skeletal Muscle of Fresh WATER Fish Tilapia mossambica (200 $\mathrm{g}$ of muscle)

\begin{tabular}{|c|c|c|c|c|c|}
\hline Step & $\begin{array}{l}\text { Total protein } \\
\text { (mg) }\end{array}$ & $\begin{array}{l}\text { Total activity } \\
(\mu \mathrm{mol} / \mathrm{hr})\end{array}$ & $\begin{array}{c}\text { Specific activity } \\
(\mu \mathrm{mol} / \mathrm{mg} \\
\text { protein } / \mathrm{hr})\end{array}$ & $\begin{array}{r}\text { Yield } \\
(\%)\end{array}$ & $\begin{array}{l}\text { Purification factor } \\
\quad \text { (-fold) }\end{array}$ \\
\hline Homogenate & $36,650.0$ & 746.7 & 0.02035 & 100.0 & - \\
\hline Heat treatment ${ }^{2)}$ & $8,804.0$ & 638.5 & 0.07270 & 85.5 & 3.6 \\
\hline \multicolumn{6}{|l|}{ Ammonium sulphate } \\
\hline$(0 \sim 80 \%)^{3)}$ & $4,380.4$ & 407.6 & 0.0935 & 54.6 & 4.6 \\
\hline First Sephadex & $1,865,6$ & 350.8 & 0.188 & 47.0 & 9.2 \\
\hline DEAE-cellulose ${ }^{5)}$ & 504.0 & 162.3 & 0.322 & 22.0 & 16.0 \\
\hline Second Sephadex ${ }^{e)}$ & 158.0 & 157.0 & 0.994 & 21.0 & 49.0 \\
\hline DEAE/Sephadex A-50 & 44.6 & 103.0 & 2.31 & 13.8 & 113.5 \\
\hline
\end{tabular}



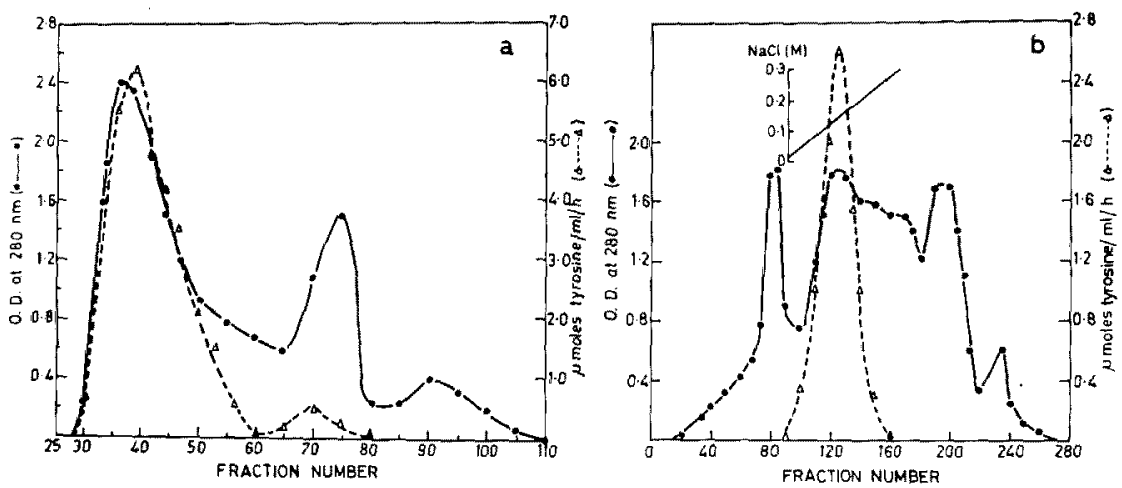

FIG. 2. Chromatographic Purification of Fish Skeletal Muscle Cathepsin D.

a, Elution pattern of $0 \sim 80 \%\left(\mathrm{NH}_{4}\right)_{2} \mathrm{SO}_{4}$ fraction on a Sephadex $\mathrm{G}-100$ bed employing $0.05 \mathrm{M}$ phosphate buffer, pH 7.2 as eluent at a flow rate of $36 \mathrm{ml} / \mathrm{hr}$ with a fraction volume of $4.8 \mathrm{ml}$. b, A DEAE cellulose column was loaded with Sephadex G-100 fraction. After passing Tris-HCl buffer $0.01 \mathrm{M}, \mathrm{pH} 8.2$, the enzyme was eluted with a gradient of sodium chloride $(0.01 \sim 0.3 \mathrm{M})$ in the above buffer. The flow rate was $60 \mathrm{ml} / \mathrm{hr}$ and the fraction volume was $5 \mathrm{ml}$.
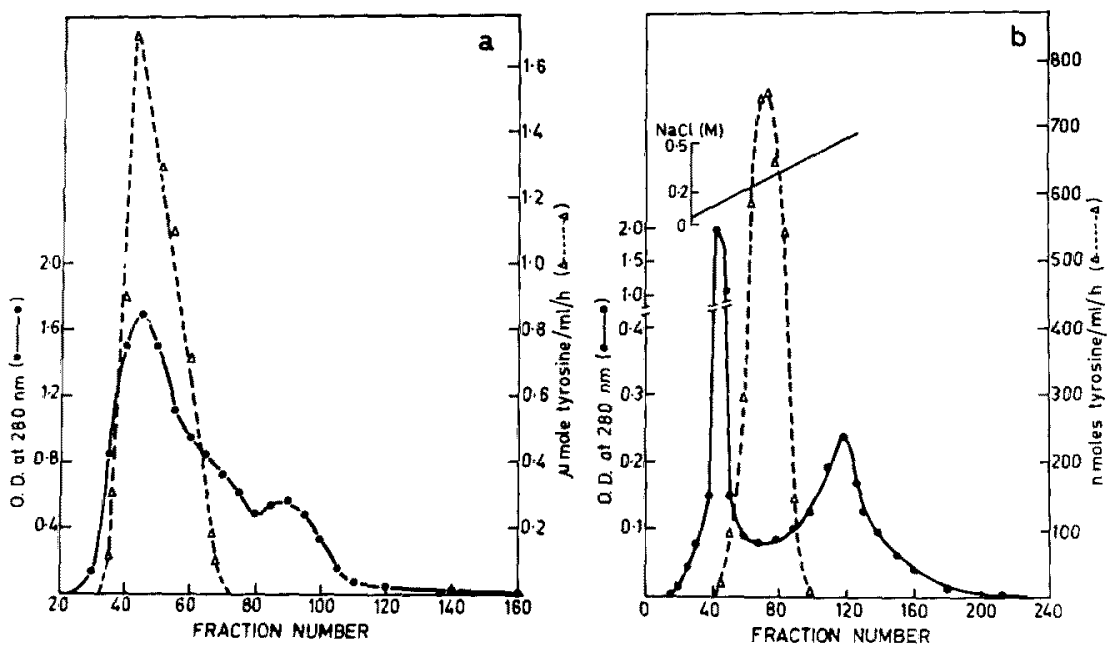

Fig. 3. Rechromatographic Profile of Fish Skeletal Muscle Cathepsin D.

a, Gel filtration pattern of cathepsin D after DEAE cellulose chromatography on Sephadex G-100. The DEAE pool was concentrated and dialysed against $0.01 \mathrm{M}$ phosphate buffer, $\mathrm{pH} 7.2$ and subjected to gel filtration employing the same buffer as the eluent. The flow rate was $18 \mathrm{ml} / \mathrm{hr}$. The fraction volume was $4.8 \mathrm{ml}$. b, Resolution of cathepsin D on DEAE-Sephadex A-50 column. The enzyme was eluted with $0.05 \mathrm{M}$ Tris- $\mathrm{HCl}$ buffer, $\mathrm{pH} 8.2$ along with a gradient of sodium chloride $(0.05 \sim 0.5 \mathrm{M})$. The flow rate was $40 \mathrm{ml} / \mathrm{hr}$ and $3 \mathrm{ml}$ fractions were collected.

fractions (tube nos. 30 52) resulted in a single sharp peak of cathepsin $\mathrm{D}$ activity which was eluted by $0.18 \mathrm{M} \mathrm{NaCl}$ as shown in Fig. 2 b. However, this preparation did not show homogeneity on electrophoresis and hence gel filtration over Sephadex G-100 was carried out for the second time, as presented in Fig. 3a. There was a 50 fold increase in the specific activity of cathepsin D with $20 \%$ recovery. However, when this preparation was subjected to electrophoresis on acrylamide gel, three bands appeared indicating non homogeneous nature of the enzyme. Further purification of the enzyme was achieved by subjecting the pooled fractions 
to DEAE-Sephadex A-50 column chromatography (Fig. 3b). The preparation having high specific activity with 114-fold purification emerged as a single sharp peak at $0.25 \mathrm{~m}$ concentration of $\mathrm{NaCl}$. There was no further purification when the enzyme was rechromatographed on Sephadex G-100 (Figure is not shown). However, a sharp peak of enzyme activity emerged which coincided with the protein peak.

The DEAE-Sephadex peak, following concentration, was subjected to disc gel electrophoresis at $\mathrm{pH}$ 8.3. A single band emerged indicating the homogeneity of the preparation (Fig. 4). However, enzyme activity could not be observed in the gel at the region of protein band apparently due to instability of cathepsin $\mathrm{D}$ at $\mathrm{pH}$ 8.3. Nevertheless, the enzyme activity could be detected in the gels following electrophoresis at $\mathrm{pH} 4.5$.

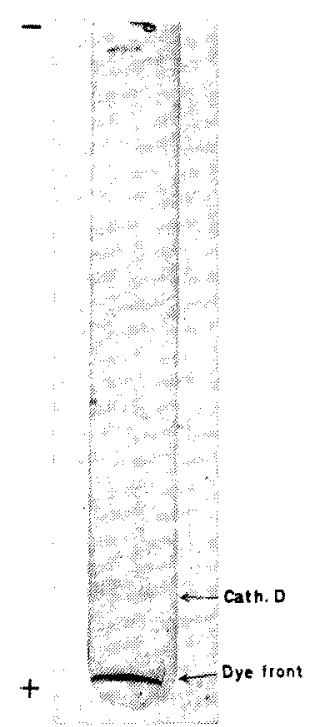

FIG. 4. Electrophoretic Pattern of Fish Muscle Cathepsin D on Polyacrylamide Gel.

$100 \mu \mathrm{g}$ of enzyme protein was loaded on the gel. Electrophoresis conditions were as described by Davis. ${ }^{21)}$

\section{Estimation of molecular weight}

By gel filtration over Sephadex G-100, blue dextran emerged with a peak at $98 \mathrm{ml}$ and cathepsin D at $180 \mathrm{ml}$. The molecular weight of cathepsin D was shown to be around 40,000

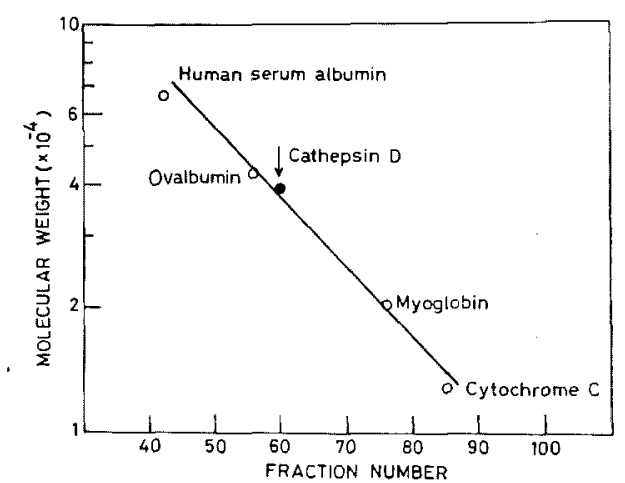

FIG. 5. Determination of Molecular Weight of Cathepsin D from the Skeletal Muscle of Fresh Water Fish Tilapia mossambica.

A column $(90 \times 2.5 \mathrm{~cm})$ of Sephadex G-100 was equilibrated with $0.05 \mathrm{~m}$ phosphate buffer, $\mathrm{pH}$ 7.2. Standard proteins $(5 \mathrm{mg})$ were each applied in a volume of $2 \mathrm{ml}$. The enzyme applied corresponded to $900 \mathrm{nmol}$ of tyrosine $/ \mathrm{hr}$. The flow rate was $20 \mathrm{ml} / \mathrm{hr}$ with $3 \mathrm{ml}$ fraction volume.

as shown in Fig. 5.

\section{Kinetics of cathepsin $D$}

The enzyme showed highest hemoglobin splitting activity at $50^{\circ} \mathrm{C}$ as shown in Fig. 6 and exhibited a bimodal $\mathrm{pH}$ dependence as

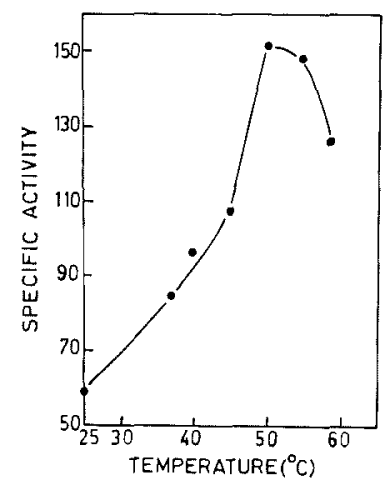

Fig. 6. Effect of Incubation Temperature on the Activity of Cathepsin D.

Dilute enzyme preparations (approx. 85 units $/ \mathrm{ml}$ at $37^{\circ} \mathrm{C}$ ) were incubated along with $1 \%$ hemoglobin buffered at $\mathrm{pH} 2.8$ (glycine- $\mathrm{HCl}, 0.1 \mathrm{M}$ ) for $1 \mathrm{hr}$ at different temperatures. At the end of incubation, the reaction was terminated by the addition of cold $10 \% \mathrm{TCA}$. Liberated assay products were estimated from appropriately diluted aliquots. ${ }^{20}$ The specific activity was expressed as nmol tyrosine released/mg protein $/ \mathrm{hr}$. 


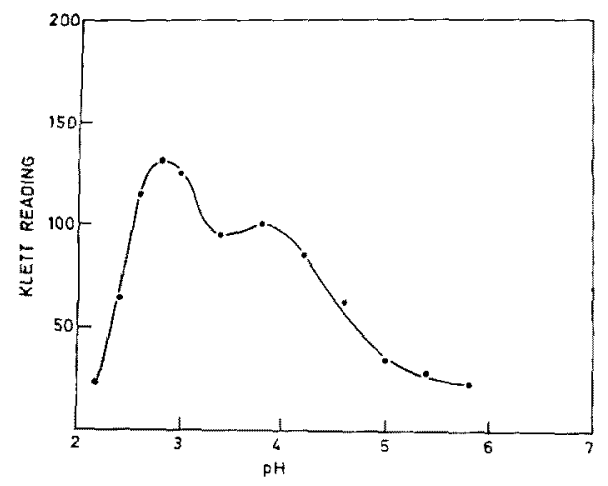

FIg. 7. pH Activity Curve of Fish Muscle Cathepsin D.

Acid denatured hemoglobin ${ }^{10)}$ was adjusted to various $\mathrm{pH}$ values by bufferring with glycine- $\mathrm{HCl}(\mathrm{pH} 2.2 \sim 3.4)$, acetic acid-sodium acetate $(\mathrm{pH} 3.6 \sim 5.8)$ and sodium phosphate ( $\mathrm{pH} 6.0 \sim 7.0$ ) buffers of $0.1 \mathrm{M}$. The $60 \mathrm{~min}$ assay of cathepsin $\mathrm{D}$ was carried out at $50^{\circ} \mathrm{C}$ as stated in the text.

depicted in Fig. 7. The highest activity of the enzyme was obtained at $\mathrm{pH} 2.8$. It was found that the reaction was linear at low concentrations of the substrate and maximal activity could be observed at $2 \%$ substrate concentration. Above this concentration the substrate seemed to inhibit the activity. The $\mathrm{Km}$ value of cathepsin $\mathrm{D}$ was found to be $0.95 \%$ hemoglobin as revealed by Lineweaver-Burk plot.

\section{Heat stability}

The pattern of thermal inactivation of cathepsin $\mathrm{D}$ at two temperature $\left(50\right.$ and $\left.60^{\circ} \mathrm{C}\right)$ is presented in Fig. $8 \mathrm{a}$ and $\mathrm{b}$. When incubated at $50^{\circ} \mathrm{C}$, the enzyme lost 20 and $35 \%$ of its activity during 10 and $60 \mathrm{~min}$ respectively. In contrast to this, thermal treatment at $60^{\circ} \mathrm{C}$ resulted in 60 and $95 \%$ inactivation of the enzyme during these periods. Nevertheless, the enzyme was quite stable at both these temperatures when incubated along with the substrate even after $2 \mathrm{hr}$ (Fig. 8 b).

\section{Storage stability}

The purified enzyme was dialysed against distilled water and stored at $-10^{\circ} \mathrm{C}$ for 3 months and the activity was assessed at regular intervals. It was found that the enzyme lost

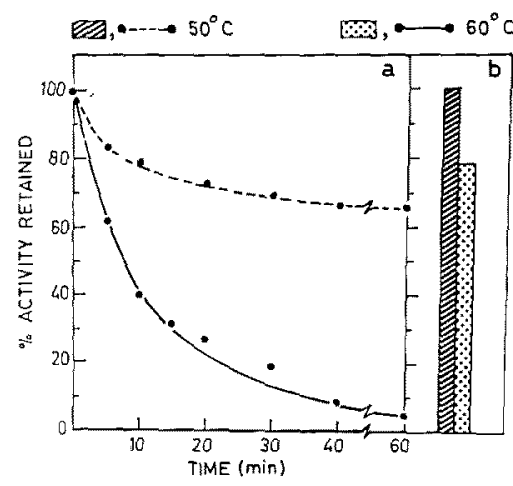

FIG. 8. Thermal Stability of Cathepsin D.

a, The enzyme was incubated in the absence of substrate for stated periods and assayed subsequently. $b$, The enzyme was incubated along with the substrate for $2 \mathrm{hr}$ and the activity determined. The assay consisted of incubating the enzyme along with bufferred substrate $(0.1 \mathrm{M}$, glycine- $\mathrm{HCl}, \mathrm{pH} 2.8)$ for $1 \mathrm{hr}$ at $50^{\circ} \mathrm{C}$. After terminating the enzyme reaction with cold $10 \%$ TCA, the products were estimated from the supernatant. ${ }^{20)}$

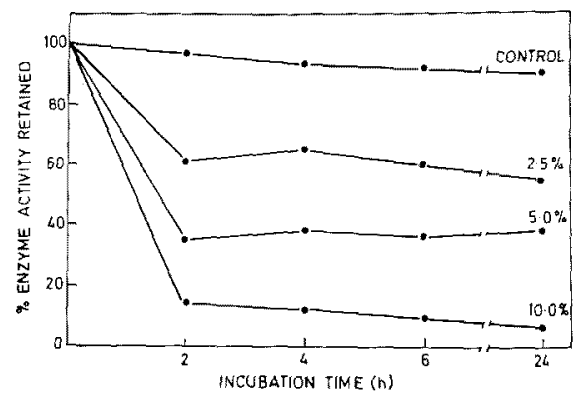

FIG. 9. Effect of Various Concentrations of Sodium Chloride on Fish Muscle Cathepsin D Activity.

Enzyme samples were incubated at room temperature with different concentrations of sodium chloride and aliquots were withdrawn at different time intervals for determining the enzyme activity.

its activity progressively during storage. At the end of three months storage a decline of $40 \%$ in the enzyme activity was noticed.

\section{Effect of activators and inhibitors}

Since salting is an accepted commercial practice in fish preservation, the effect of varying concentrations of $\mathrm{NaCl}$ on the enzyme was ascertained. Nearly complete inhibition of cathepsin D activity was observed at $10 \%$ $\mathrm{NaCl}$ level (Fig. 9).

The effect of metal ions and other substances 
on cathepsin $\mathrm{D}$ activity was studied at a final concentration of $5 \times 10^{-3} \mathrm{M}$ of effectors in the enzyme solution under standard conditions. The compounds tested included cysteine, dithioerythreitol, $\mathrm{CaCl}_{2}, \mathrm{NiCl}_{2}, \mathrm{CuSO}_{4}, 8$-hydroxyquinoline, $\mathrm{FeCl}_{3}$ and para-chloromercuribenzoate $(p-\mathrm{CMB})$. None of these agents including dithioerythreitol and $p$-CMB could appreciably alter the activity of cathepsin $\mathrm{D}$.

\section{DISCUSSION}

Cathepsin D is widely distributed throughout many animal tissues. ${ }^{26)}$ The tissue fractionation studies of Canonico and Bird ${ }^{5)}$ have demonstrated that $95 \%$ of cathepsin $\mathrm{D}$ activity is located in the lysosomes of muscle cells. Some early studies of fish muscle cathepsins have been carried out by Siebert and coworkers. $^{26,27)}$ Several attempts have also been made to purify cathepsins from the skeletal muscle of fish such as salmon, ${ }^{287}$ albacore ${ }^{29}$ and winter flounder. ${ }^{2}$ The major characteristics of this enzyme include specificity akin to pepsin, ability to digest hemoglobin, dependence on acidic $\mathrm{pH}$, lack of any activators and inability to cleave synthetic peptides. Siebert and Schmitt ${ }^{27}$ ) have been able to purify cod muscle cathepsin 2500-fold. Although the present enzyme preparation from the skeletal muscle of fish Tilapia mossambica, showed only 114fold purification, it seemed to be homogeneous electrophoretically. The molecular weight of cathepsin $\mathrm{D}$ from this fish species was observed to be approximately 40,000. Considerable variation exists among the molecular weight values reported for cathepsin $\mathrm{D}$ from different tissues. Press et al. ${ }^{30}$ obtained a molecular weight of 58,000 for bovine spleen cathepsin D which was confirmed by Keilova. ${ }^{31)}$ Reddi et al. ${ }^{2)}$ demonstrated that molecular weight of cathepsin D of winter flounder was 32,000 . Small molecular weights in the range of 10,000 $\sim 21,000$ have also been proposed..$^{28,321}$ However, the molecular weight of 40,000 obtained in the present investigation corroborates the observation of Cunningham and Tang ${ }^{33)}$ and Ferguson et $a l^{34)}$ on cathepsin D from other mammalian sources.

The data on the degradation of endogenous sarcoplasmic protein by the crude enzyme preparation indicate involvement of cathepsin $\mathrm{D}$ in tissue autolysis. The release of tyrosine equivalents was more rapid at $\mathrm{pH} 5.0$ than at a lower $\mathrm{pH}$ value of 3.8. This could be attributed to the concerted action of all cathepsin enzyme especially that of $B, C$ and $D$ in accomplishing total proteolysis as suggested by Coffey and de Duve ${ }^{35)}$ and Tappel. ${ }^{36)}$ Occurrence of maximal proteolysis at $\mathrm{pH} 5.0$ assumes more significance in the light of available information on the $\mathrm{pH}$ of post-mortem muscle which is known to be in the vicinity of $5.0,{ }^{37}$ ) which apprently could accelerate catabolic processes associated with autolytic degradation of tissue components.

The bimodal $\mathrm{pH}$ dependence curve exhibited by fish muscle cathepsin D raises an interesting point as to whether the preparation contained two enzymes with different $\mathrm{pH}$ optima. However, the single band in polyacrylamide gel electrophoresis indicating homogeneity as well as the separation of the enzyme as a single peak on DEAE Sephadex A-50 chromatography may rule out such a possibility. Purified porcine spleen cathepsin D has also been shown to exhibit similar $\mathrm{pH}$ characteristics. ${ }^{33}$ )

No activation or inhibitory effect was noticed by metalic salts or sulphydryl reagents as observed for the enzyme from most other sources. Heavy metal ions such as $\mathrm{Fe}^{3+}, \mathrm{Hg}^{2+}$ and $\mathrm{Pb}^{2+}$ are reported to inhibit mammalian cathepsin D. ${ }^{23)}$ Although sulphydryl groups are presumed to be necessary for the activity of cathepsins $B$ and $C^{38,39}$ these did not seem to be essential for cathepsin D. ${ }^{16,28,25,39,34\}}$

The high temperature optima and heat stability seems to be a characteristic property of fish muscle cathepsin D. Although it is customary to assay lysosomal cathepsin D at $37^{\circ} \mathrm{C},^{17,23,25)}$ temperatures ranging from $40 \sim$ $49^{\circ} \mathrm{C}$ have been suggested for assaying muscle cathepsin D. ${ }^{29,40}$ The muscle enzyme from Tilapia fish exhibited an optimum temperature of $50^{\circ} \mathrm{C}$. Even after two hour's incubation at $60^{\circ} \mathrm{C}$ along with the substrate, the inactivation 
of the enzyme was not significant. However, in the absence of the substrate, exposure to $60^{\circ} \mathrm{C}$ for the same duration resulted in the destruction of the enzyme to the extent of $95 \%$. The inactivation during the same period at $50^{\circ} \mathrm{C}$ was only $35 \%$. These observations may suggest that the substrate offered protection to the enzyme. The relative stability of fish muscle cathepsin D to high temperatures has to be reckoned in the thermal processing of fish muscle, since inadequate heat treatment could lead to retention of the enzyme activity. Sodium chloride is known to preserve fish muscle by controlling microbial spoilage. ${ }^{41,42)}$ The present data indicate that inhibition of cathepsin $D$ could also be accomplished by salt treatment. It is interesting to note that though $\mathrm{NaCl}$ was inhibitory to the enzyme, $\mathrm{KCl}$ did not exhibit this effect and was in fact employed in the extraction of the enzyme. The differential effects of these salts on the activity of cathepsin $D$ are being investigated.

\section{REFERENCES}

1) F. C. Parrish Jr., D. E. Goll, W. J. Newcomb II, B. O. de Lumen, H. M. Chaudhary and E. A. Kline, J. Food Sci., 34, 196 (1969).

2) P. K. Reddi, S. M. Constantinides and H. A. Dymsza, J. Food. Sci, 37, 643 (1972).

3) R.C. Whiting, M. W. Montgomery and A. F. Anglemier, J. Food. Sci., 40, 854 (1975).

4) K. A. Caldwell, J. Agri. Food Chem., 18, 276 (1970).

5) P. G. Canonico and J. W. C. Bird, J. Cell Biol,, 45, 321 (1970).

6) J. W. C. Bird, T. Berg, A. Milanesi and W. T. Stauber, Comp. Biochem. Physiol., 30, 457 (1969).

7) A. A. Milanesi and J. W. C. Bird, Comp. Biochem. Physiol, 41, 573 (1972).

8) A. A. Milanesi and J. W. C. Bird, Comp. Biochem. Physiol., 41, 593 (1972).

9) W. T. Stauber, P. G. Canonico, A. A. Milanesi and J. W. C. Bird, Comp. Biochem. Physiol, 50, 379 (1975).

10) M. F. Eino and D. W. Stanley, J. Food Sci, 38, 45 (1973).

11) T. R. Dutson and R. A. Lawrie, J. Food Technol, 9, 43 (1974).

12) P. Harikumar, V. Ninjoor, S. B. Warrier and U.S. Kumta, J. Agri. Food Chem., 22, 530 (1974).

13) R. R. Eitenmiller, J. Food Sci., 39, 6 (1974).
14) P. Sepulveda, J. Marciniszyn, D. Liu and J. Tang, J. Biol. Chem., 250, 5082 (1975).

15) I. N. Hsu, L. T. J. Delbare and M. N. G. James, Nature, 266, 140 (1977).

16) V. Turk, I. Kregar, F. Gubensek, S. Lapanje, I. Urh and M. Kovacic, Acta Biol. Med. Germ., 36, 1531 (1977).

17) I. Ishikawa and G. Cimasoni, Biochim. Biophys, Acta, 480, 228 (1977).

18) A. Moriyama and K. Takahashi, J. Biochem., 83, 441 (1978).

19) M. L. Anson, J. Gen. Physiol., 22, 79 (1939).

20) G. L. Miller, Anal. Chem., 31, 964 (1959).

21) B. J. Davis, Ann. N. Y. Acad. Sci., 121, 404 (1964).

22) W. N. Fishbein, Anal. Biochem., 46, 388 (1972).

23) J. F. Woessner, Jr. and R. J. Shamberger, J. Biol. Chem., 246, 1951 (1971).

24) F. J. King, J. Food Sci., 31, 649 (1966).

25) A. J. Barrett, in "Proteinases in Mammalian Cells and Tissues" ed. by A. J. Barrett, North-Holland Publishing Co., Amsterdam, 1977, p. 209.

26) G. Siebert, A. Schmitt and G. Traxler, $Z$. Physiol, Chem., 332, 160 (1963).

27) G. Siebert and A. Schmitt, in "The Technology of Fish Utilization," ed. by R. Kreuzer, Fishing News (Books) Ltd., London, 1965, p. 47.

28) C. Y. Ting, M. W. Montgomery and A. F. Anglemier, J. Food Sci, 33, 617 (1968).

29) H. S. Groninger, Jr., Archs. Biochem. Biophys., 108, 175 (1964).

30) E. M. Press, R. R. Porter and J. Cebra, Biochem. J., 74, 501 (1960).

31) H. Keilova, in "Tissue Proteinases," ed. by A. J. Barrett and J. T. Dingle, North-Holland Publishing Co., Amsterdam, 1971, p. 45.

32) A. I. Sapolsky and J. F. Woessner, Jr, J. Biol. Chem., 247, 2069 (1972).

33) M. Cunningham and J. Tang, J. Biol. Chem., 251, 4528 (1976).

34) J. B. Ferguson, J. R. Andrews, I. M. Voynick and J. S. Fruton, J. Biol. Chem., 248, 6701 (1973).

35) J. W. Coffey and C. de Duve, J. Biol. Chem., 243, 3255 (1968).

36) A. L. Tappel, in "Lysosomes in Biology and Pathology," Vol. 2, ed, by J. T. Dingle and H. B. Fell, North-Holland Publishing Co., Amsterdam, 1969, p. 207.

37) J. R. Whitaker, in "Principles of Enzymology for the Food Sciences," Marcel Dekker Inc., New York, 1972, p. 14.

38) V. Ninjoor, S. L. Taylor and A. L. Tappel, Biochim. Biophys. Acta, 370, 308 (1974).

39) F. L. Huang and A. L. Tappel, Biochem. Biophys. Acta, 268, 527 (1972).

40) Y. Makinodan and S. I. Keda, Bull Japan Soc. Sci. Fish., 35, 672 (1969).

41) T. A. Roberts and M. Ingram, J. Food. Technol,, 8, 467 (1973).

42) A. H. W. Hanschild and R. Hilsheimer, J. Food Protection, 42, 245 (1979). 